\title{
Study on the Mechanism of Efficient Extracellular Expression of Toxic Streptomyces Phospholipase D in Brevibacillus Choshinensis Under $\mathrm{Mg}^{2+}$ Stress
}

\author{
Shaofeng Chen \\ Xiamen University \\ Weide xiong \\ Xiamen Medical College \\ Xurui Zhao \\ Xiamen University \\ Weiyi Luo \\ Xiamen University \\ Xuhui Yan \\ Xiamen University \\ Yinghua Lu \\ Xiamen University \\ Cuixue Chen \\ Xiamen University \\ Xueping Ling ( $\nabla$ xpling@xmu.edu.cn ) \\ Xiamen University
}

\section{Research Article}

Keywords: Phospholipase D, Brevibacillus choshinensis, Magnesium stress, P2 promoter, Ion perturbation.

Posted Date: January 11th, 2022

DOI: https://doi.org/10.21203/rs.3.rs-1225525/v1

License: (c) (i) This work is licensed under a Creative Commons Attribution 4.0 International License. Read Full License

Version of Record: A version of this preprint was published at Microbial Cell Factories on March 19th, 2022. See the published version at https://doi.org/10.1186/s12934-022-01770-z. 


\section{Abstract}

\section{Background}

Phospholipase D (PLD) has significant advantages in the food and medicine industries due to its unique transphosphatidylation. However, the high heterologous expression of PLD is limited by its cytotoxicity. The present study sought to express the strong extracellular protein of PLD in the non-pathogenic Brevibacillus choshinensis (B. choshinensis).

Results

The extracellular PLD was effectively expressed by the strong promoter (P2) under $\mathrm{Mg}^{2+}$ stress, with the highest activity of $1.0 \times 10^{4} \mathrm{U} \cdot \mathrm{L}^{-1}$. The inductively coupled plasma-mass spectrometry (ICP-MS) results elucidated that the fast expression of PLD by P2 promoter without $\mathrm{Mg}^{2+}$ stress induced the ionic homeostasis perturbation caused by the highly enhanced $\mathrm{Ca}^{2+}$ influx, leading to cell injury or death. Under $\mathrm{Mg}^{2+}$ stress, $\mathrm{Ca}^{2+}$ influx was significantly inhibited, and the strengths of P2 promoter and HWP gene expression were weakened. The study results revealed that the mechanism of $\mathrm{Mg}^{2+}$ induced cell growth protection and PLD expression might be related to the lowered strength of PLD expression by P2 promoter repression to meet with the secretion efficiency of $B$. choshinensis, and the redistribution of intracellular ions accompanied by decreased $\mathrm{Ca}^{2+}$ influx.

\section{Conclusions}

The PLD production was highly improved under $\mathrm{Mg}^{2+}$ stress. By ICP-MS and qPCR analysis combined with other results, the mechanism of the efficient extracellular PLD expression under $\mathrm{Mg}^{2+}$ stress was demonstrated. The relatively low-speed PLD expression during cell growth alleviated cell growth inhibition and profoundly improved PLD production. These results provided a potential approach for the large-scale production of extracellular PLD and novel insights into PLD function.

\section{Background}

Phospholipase D (PLD, EC 3.1.4.4) could synthesize novel medicinal bioactive phospholipids [1] by introducing its functional polar heads into the common phospholipids through the transphosphatidyl reaction. The phosphatidyl derivatives, including phosphatidylglycerol (PG) $[2,3]$, phosphatidyl ethanolamine (PE) [4], phosphatidylserine (PS) [5-7], and phosphatidylinositol (PI) [8] have significant advantages in the food and medicine industries. For instance, $\mathrm{PS}$, the primary component of nerves in the brain [9-11], could exert a positive effect on the age-related memory disorders [12], Alzheimer's disease [13], and attention deficit and hyperactivity disorder (ADHD) [14]. In recent years, numerous novel phospholipids with anti-cancer and antioxidant activities have been developed and utilized by PLD, such as phosphatidyl-batilol [15], phosphatidyl glucose [16], phosphatidyl serinol [17], indicating the wide application prospect of PLD. 
Although PLD is abundant in nature, the low content of wild-type PLD and difficulty in extraction have affected its industrial production to meet the market demand [10]. Therefore, many researchers have attempted to isolate strains with high PLD production [5] or develop the PLD heterologous expression systems. So far, PLDs from different sources have been successfully expressed in Escherichia coli (E. coli) [18-20], Streptomyces lividans [21, 22], Pichiapastoris [23], and Bacillus. subtilis [24], but their extracellular synthesis with high-efficiency is still strenuous due to their cytotoxicity [20,21]. According to reports, the highest PLD production in E. coli Top10 was $1100 \mathrm{U} / \mathrm{mL}$ [25], but it was intracellular expression. The extracellular expression systems have recently gained increased attention due to the easy separation and production of extracellular PLD. However, the reported highest PLD level (under $10^{2}$ $\mathrm{U} / \mathrm{mL}$ ) could not meet the industrial requirements. Therefore, extensive research on the extracellular expression protocols is highly warranted.

The expression system of $B$. choshinensis (formerly Bacillus brevis HPD31) is more convenient for secreted active proteins production due to strong extracellular protein secretion [26, 27]. This system has also been extensively used to produce various foreign proteins, including cellulose [28], metalloproteinase [29], and nanobody [30]. Furthermore, $B$. choshinensis has been engineered to produce nearly negligible extracellular proteases ensuring the safety of the foreign protein produced and eliminating spore forming capacity. This strain has also been confirmed to be nonpathogenic, with significant potential in the food microbiology industry [26]. Therefore, in this study, the $B$. choshinensis expression system was employed for PLD production.

Accumulating studies have reported that a substantial heterologous expression of PLD might cause significant damage to the cell. Based on this report, a weak promoter P5 was first used to express PLD extracellularly by $B$. choshinensis. After the PLD gene was successfully expressed in $B$. choshinensis, the promoter was replaced with a stronger promoter P2 to improve the PLD production, which showed significant increase under magnesium ion containing medium. Moreover, the possible regulatory mechanisms from the level of gene transcription to intracellular ion distribution were explored. The results showed that $B$. choshinensis could be a potential approach for expressing substantial amounts of heterologous PLD.

\section{Results}

\section{Expression of PLD by the recombinant $B$. choshinensis with two different promoters}

In this study, two different recombinant $B$. choshinensis expressing phospholipase $D$ were successfully constructed by using two different plasmid vectors, namely pNY326 (weak P5 promoter) and pNCMO2 (strong P2 promoter).

When the transformed strains were cultured on the plate, the plate culture showed the presence of $B$. choshinensis/pNY326-PLD, while no any trace of B. choshinensis/PNCMO2-PLD. The promoters of the 
two expression vectors had significant differences in strength. As depicted in Fig. 1, $B$. choshinensis/pNY326-PLD containing P5 promoter was consistent with the growth of the control group and expressed a small amount of PLD, which indicated that the low expression of PLD by $B$. choshinensis under weak constitutive promoter P5 would not damage the host cell. It was speculated that the strength of the P2 promoter in pNCM02-PLD was much greater than P5 promoter [26] in pNY326PLD, inducing strong expression of PLD, but high PLD expression severely inhibited cell growth due to its cytotoxicity. Therefore, for improving PLD expression, two problems need further consider: One is how to weaken the strength of the P2 promoter, and the other is how to reduce the adverse effects of PLD on cell growth.

According to reports, magnesium ions could specifically inhibit the activity of P2 promoter [31] and alleviate the cytotoxicity of PLD [20]. Therefore, in this study, $60 \mathrm{mM}$ of $\mathrm{MgSO}_{4}$ was added to the transformation plate to culture B. choshinensis/pNCMO2-PLD. As depicted in Fig. 2, $B$. choshinensis/pNCMO2-PLD showed normal growth, with a significant increase in PLD production. Comparing the growth of the two recombinant cells (B.choshinensis/pNY326-PLD was cultured in the TM medium and B.choshinensis/pNCMO2-PLD was cultured in the TM medium with $60 \mathrm{mM} \mathrm{MgSO}_{4}$ ) (Fig. 3), the higher extracellular activity of PLD $(2.03 \mathrm{U} / \mathrm{mL})$ was obtained by the pNCMO2-PLD expression system, which was 67-folds than pNY326-PLD $(0.03 \mathrm{U} / \mathrm{mL})$. These results indicated that the strong promoter could enhance PLD expression under magnesium ion stress, which plays a vital role in PLD expression by B.choshinensis/pNCMO2-PLD. However, its mechanism needs further investigation.

\section{Determination of the culture medium}

In the initial experiments, the TM medium was used to culture the cells. However, it found the recombinant cells showed unstable growth, suggesting that the TM medium was not optimal for PLD expression. Therefore, we first compared three culture medium, including 2SY, TM medium, and a fermentation medium from $B$. choshinensis to efficiently express the pullulan [32] under $60 \mathrm{mM} \mathrm{MgSO}_{4}$, then chosed the fermentation medium for futher optimization. The results are depicted in Fig. S1 and S2. After optimization, the modified fermentation medium contained $30.0 \mathrm{~g} / \mathrm{L}$ glucose, $30.0 \mathrm{~g} / \mathrm{L}$ beef extract, $25.0 \mathrm{~g} / \mathrm{L}$ yeast extract, and $60 \mathrm{mM} \mathrm{MgSO}_{4}$, which increased PLD production by 7 times.

\section{Effect of metal ions on phospholipase $D$ expression by $B$. choshinensis}

The optimal concentration of $\mathrm{Mg}^{2+}$ was investigated because $\mathrm{Mg}^{2+}$ could increase PLD production in $B$. choshinensis. As shown in Fig. 4a, the biomass exhibited a slight increase at different $\mathrm{Mg}^{2+}$ concentration, while the PLD activity continued to increase until it reached a peak value of $9.8 \mathrm{U} / \mathrm{mL}$ at $100 \mathrm{mM} \mathrm{Mg}^{2+}$. 
The result showed that magnesium ion had a positive promoting effect on PLD expression in $B$. choshinensis/pNCMO2-PLD, speculating similar effects from other metal ions. Therefore, the effects of $\mathrm{Na}^{+}, \mathrm{K}^{+}, \mathrm{Ca}^{2+}$, and $\mathrm{Mg}^{2+}$ on cell growth and PLD production were investigated in the modified fermentation medium. As depicted in Fig. 4b, only $\mathrm{Mg}^{2+}$ and $\mathrm{K}^{+}$stimulated cell growth to some extent, while $\mathrm{Ca}^{2+}$ and $\mathrm{Na}^{+}$inhibited cell growth. For PLD activity, all ions had promoting effect, but the growth was highly stimulated in the presence of $\mathrm{Mg}^{2+}$, reaching the highest activity of $10.09 \mathrm{U} / \mathrm{mL}$. So, the modified fermentation medium with $100 \mathrm{mM} \mathrm{MgSO}_{4}$ (named as medium A) was used as the optimal medium in the following experiments. Also, the anions of $\mathrm{Na}^{+}, \mathrm{K}^{+}$, and $\mathrm{Mg}^{2+}$ groups were all $\mathrm{SO}_{4}{ }^{2-}$, but the PLD activity was significantly different, which indicated that anion was not the key factor for promoting the PLD activity.

\section{Analysis of secreted PLD production by SDS-PAGE}

In order to understand how $\mathrm{Mg}^{2+}$ affects PLD production, SDS-PAGE analysis was performed. As shown in Fig. 5 , a band about $64 \mathrm{kDa}$ in protein samples of $B$. choshinensis/pNCMO2-PLD was detected (lanes $1,2,6,7)$, while there was no obvious band at $64 \mathrm{kDa}$ in protein samples of $B$. choshinensis (lanes 3,5$)$. It indicated that PLD was successfully expressed in recombinant cells. Comparing extracellular protein samples showed in lane 6 and $7, \mathrm{Mg}^{2+}$ induced more PLD expressed and secreted, which is in good agreement with the PLD activity value (Fig. 4a). Besides, expressing PLD could cause sever protein leakage (lanes $5,6,7)$ due to its cytotoxicity. Comparing intracellular protein samples showed in lane 1 and 2, there were PLD detected. It suggested PLD might accumulate in cells. Furthermore, lane 2 presented less PLD than lane 1, indicating more accumulated intracellular PLD could inhibit its extracellular expression and secretion, and $\mathrm{Mg}^{2}$ might hinder intracellular PLD to accumulate and benefit PLD expression and secretion.

\section{Ion perturbation in the PLD-imposed cells}

Xiong et al. found that the PLD-imposed cells in E.coli underwent ion perturbations, resulting in cell injury or cell death. $\mathrm{Na}^{+}$stress protects the PLD-imposed cells by improving oxidative phosphorylation through a positive change in the membrane potential via redistribution of $\mathrm{Na}^{+} / \mathrm{K}^{+}$inside and outside the cell [25]. Therefore, $B$. choshinensis/pNCMO2 was cultured in medium A without $\mathrm{Mg}^{2+}$ (NP group), and $B$. choshinensis/pNCMO2-PLD was cultured in medium $A$ (EPMg group) and without $\mathrm{Mg}^{2+}$ (EP group) to determine whether $\mathrm{Mg}^{2+}$ has a similar regulatory mechanism for PLD expression. The changes of seven ions in cells $\left(\mathrm{Na}^{+}, \mathrm{K}^{+}, \mathrm{Mg}^{2+}, \mathrm{Ca}^{2+}, \mathrm{Fe}^{2+/ 3+}, \mathrm{Zn}^{2+}\right.$ and $\left.\mathrm{Mn}^{2+}\right)$ were evaluated in the NP, EP and EPMg groups.

We initially focused on ion distribution at $24 \mathrm{~h}$ (Fig. 6a and 6b) and found the same change trend in the three groups. For instance, $\left[\mathrm{Na}^{+}\right]$and $\left[\mathrm{Fe}^{2+/ 3+}\right]$ decreased, while $\left[\mathrm{K}^{+}\right],\left[\mathrm{Mg}^{2+}\right],\left[\mathrm{Ca}^{2+}\right],\left[\mathrm{Mn}^{2+}\right]$, and $\left[\mathrm{Zn}^{2+}\right]$

increased, resulting in similar cell growth. Compared with the EP group, higher $\left[\mathrm{Mg}^{2+}\right]$ and $\left[\mathrm{Mn}^{2+}\right]$ with an 
increasing rate of $67.86 \%$ and $61.62 \%$, and lower $\left[\mathrm{K}^{+}\right]$and $\left[\mathrm{Ca}^{2+}\right]$ with a decreasing rate of $23.91 \%$ and $54.17 \%$ were observed in the EPMg group. In $36 \mathrm{~h}$, most of the ions maintained a steady-state, while $\left[\mathrm{Ca}^{2+}\right]$ and $\left[\mathrm{Zn}^{2+}\right]$ showed an increase of $101.93 \%$ and $140.32 \%$ (Fig. $6 \mathrm{c}$ and $6 \mathrm{~d}$ ). Meanwhile, the expressed PLD exhibited significant changes in $\left[\mathrm{K}^{+}\right],\left[\mathrm{Mg}^{2+}\right]$, and $\left[\mathrm{Ca}^{2+}\right]$, suggesting that PLD expression might affect the cell growth status by influencing ion distribution. Under $\mathrm{Mg}^{2+}$ stress, $\left[\mathrm{K}^{+}\right]$and $\left[\mathrm{Mg}^{2+}\right]$ increased by $198.55 \%$ and $287.83 \%$, while $\left[\mathrm{Na}^{+}\right]$and $\left[\mathrm{Ca}^{2+}\right]$ decreased by $31.08 \%$ and $66.31 \%$, respectively. These results demonstrate that $\mathrm{Mg}^{2+}$ stress changes the regulation of some intracellular ions in the PLDimposed cells, which might change the cell physiology status.

The changes of ion contents in the cells were not consistent at different growth periods under $\mathrm{Mg}^{2+}$ stress. Notably, $\left[\mathrm{Ca}^{2+}\right]$ exhibited extraordinary change at $24 \mathrm{~h}$ and $36 \mathrm{~h}$. Compared to the NP group, [ $\left.\mathrm{Ca}^{2+}\right]$ of the EP group significantly increased. When $\mathrm{Mg}^{2+}$ stress was introduced to the medium (EPMg group), $\left[\mathrm{Ca}^{2+}\right]$ reduced sharply, indicating that $\left[\mathrm{Ca}^{2+}\right]$ might regulate cell growth. Comparing the changes of ions in three groups at $36 \mathrm{~h},\left[\mathrm{~K}^{+}\right]$and $\left[\mathrm{Mg}^{2+}\right]$ were found to have the lowest concentration in the EP group and the highest concentration in the EPMg group. On the contrary, $\left[\mathrm{Ca}^{2+}\right]$ had the highest value in the EP group and the lowest value in the EPMg group. The combined results of Fig. $6 \mathrm{e}$ and $6 \mathrm{f}$ suggest that the addition of $\mathrm{Mg}^{2+}$ in the PLD-imposed cells could keep the cells with low $\left[\mathrm{Ca}^{2+}\right]$, high $\left[\mathrm{K}^{+}\right]$, and $\left[\mathrm{Mg}^{2+}\right]$ contents, which is beneficial for cell growth.

The toxic effect of PLD on cells was minute due to the low level of PLD expression in the early growth stage. Therefore, the cell growth of both EP and EPMg groups was slightly lower than the NP group before $24 \mathrm{~h}$ (Fig. 6e). From 24 h, PLD expression started to increase to a great extent, which significantly changed the ion distribution of the experimental group, inducing cells showed significant different growth states. Of the three groups, the biomass in the EP group was the lowest at $36 \mathrm{~h}$, which began to decline after $36 \mathrm{~h}$. The biomass in the EPMg group surpassed the NP group at $36 \mathrm{~h}$ and continued to rise. As depicted in Fig. $6 \mathrm{~b}$ and $6 \mathrm{e},\left[\mathrm{Ca}^{2+}\right]$ of the EP group with the worst growth state was significantly higher than the other two groups at $24 \mathrm{~h}$ and $36 \mathrm{~h}$. However, the EPMg group with the best growth state at $36 \mathrm{~h}$ was significantly lower than the EP and NP groups, indicating that PLD significantly increased the intracellular $\left[\mathrm{Ca}^{2+}\right]$ content, which was harmful to the cells. In contrast, the addition of $\mathrm{Mg}^{2+}$ could significantly inhibit the increase of $\mathrm{Ca}^{2+}$ induced by PLD expression to alleviate the toxic effect of PLD on cells, resulting in the continuous increase of cell growth and PLD expression. Meanwhile, the growth of $B$. choshinensis was inhibited under $\mathrm{Ca}^{2+}$ stress (Fig. 6a), indicating $\mathrm{Ca}^{2+}$ to be an essential factor affecting the growth of $B$. choshinensis.

The intracellular concentrations of four ions $\left(\mathrm{Na}^{+}, \mathrm{K}^{+}, \mathrm{Mg}^{2+}, \mathrm{Ca}^{2+}\right)$ were investigated from $12 \mathrm{~h}$ to $60 \mathrm{~h}$ to further analyze the effect of ion changes. Compared with the NP group, $\left[\mathrm{Na}^{+}\right]$showed a similar decreasing trend at the first $24 \mathrm{~h}$, while $\left[\mathrm{K}^{+}\right]$had a similar increase in the EP and EPMg groups (Fig. 7a and $7 \mathrm{~b}$ ). However, after $24 \mathrm{~h},\left[\mathrm{~K}^{+}\right]$began to decrease accompanied by an increase in $\left[\mathrm{Na}^{+}\right]$content in the EP group, while in the EPMg group, $\left[\mathrm{K}^{+}\right]$continued to increase accompanied by a steady low [ $\left.\mathrm{Na}^{+}\right]$. In $24 \mathrm{~h}$, 
the continued PLD expression in the cell caused $\mathrm{K}^{+}$efflux and $\mathrm{Na}^{+}$influx in the EP group, which was harmful to the cells [25]. However, the addition of $\mathrm{Mg}^{2+}$ could regulate the change in ions. As depicted in Fig. $7 \mathrm{c},\left[\mathrm{Mg}^{2+}\right]$ in the EPMg group showed a higher growth rate than the other two groups. It is reported that $\mathrm{Mg}^{2+}$ could enhance the activity of $\mathrm{Na}^{+}-\mathrm{K}^{+}$-ATPase [33], thereby triggering $\mathrm{K}^{+}$influx and $\mathrm{Na}^{+}$efflux in the EPMg group, keeping $\left[\mathrm{Na}^{+}\right]$lower and $\left[\mathrm{K}^{+}\right]$higher inside the cells to promote cell growth. As depicted in Fig. $7 \mathrm{~d},\left[\mathrm{Ca}^{2+}\right]$ in the EP group with the lowest biomass had a high concentration. In contrast, the EPMg group with the highest biomass had low $\left[\mathrm{Ca}^{2+}\right]$ during the whole process. Although low $\left[\mathrm{Ca}^{2+}\right]$ was observed in the NP group before $24 \mathrm{~h}$, it began to increase after $36 \mathrm{~h}$, showing a sharp increase. $\left[\mathrm{Ca}^{2+}\right]$ of the EP group simultaneously exhibited similar increasing trend after $36 \mathrm{~h}$. As depicted in Fig. 6e, the EPMg group showed increased biomass, while the other two groups showed a decreased biomass after $36 \mathrm{~h}$. The results suggested that the growth of $B$. choshinensis was coupled with the intracellular $\left[\mathrm{Ca}^{2+}\right]$ and low intracellular $\left[\mathrm{Ca}^{2+}\right]$ was beneficial for cell growth.

Xiong et al. expressed PLD in E. coli and found that it could cause a continuous influx of $\mathrm{Na}^{+}$, the outflow of $\mathrm{K}^{+}$, and increase of intracellular $\mathrm{Ca}^{2+}$, while cations stress (especially $\mathrm{Na}^{+}$) alleviated cell growth inhibition and profoundly increased PLD production by redistributing the ions inside and outside the cell. The effect of salt stress on PLD expression was consistent with our study results. However, PLD expression in $B$. choshinensis showed a different phenomenon without any continuous influx of $\mathrm{Na}^{+}$. Therefore, it was speculated that the effect of $\mathrm{Mg}^{2+}$-induced protection on cell growth and PLD expression might be related to the $\mathrm{P} 2$ promoter expression.

\section{Transcription level of PLD and HWP genes in B. choshinensis/pNCMO2-PLD under $\mathrm{Mg}^{2+}$ stress}

HPD31 Wall Protein (HWP) is the cell wall protein secreted by B. choshinensis, whose expression could also be regulated by the P2 promoter $[34,35]$. Therefore, the analysis of HWP expression level could further reflect the level of $\mathrm{P} 2$ promoter strength.

As depicted in Fig. 8a and 8b, the transcriptional levels of PLD and HWP genes in the EP group were consistent with the EPMg group at $12 \mathrm{~h}$, but both increased sharply in the EP group at $24 \mathrm{~h}$, which were 5.14 times and 4.52 times higher than at $12 \mathrm{~h}$, respectively. Subsequently, the transcription level of PLD and HWP decreased significantly at $36 \mathrm{~h}$. It might be attributed to PLD accumulation which induced a toxic effect on cell growth (Fig. 6e), resulting in the death of the recombinant strain and decreased gene expression. As for the EPMg group, the transcription levels of PLD and HWP exhibited minute changes at $24 \mathrm{~h}$ and $36 \mathrm{~h}$ compared to $12 \mathrm{~h}$. The results indicated that $\mathrm{Mg}^{2+}$ reduced the strength of the $\mathrm{P} 2$ promoter reflected by the decreased transcriptional level of the HWP gene, further maintaining the PLD gene at a relatively low transcription level during cell growth. Therefore, the toxic effect caused by highly expressed PLD was inhibited, which was conducive to the continuous cell growth and expression of PLD in $B$. choshinensis (Fig. 7a and 7b). 
As depicted in Fig. 6e, cell growth in three groups was consistent before $24 \mathrm{~h}$, but it changed after $24 \mathrm{~h}$. The biomass of the NP and EP groups gradually declined after $36 \mathrm{~h}$, showing the worst growth state in the EP group. In contrast, the biomass of the EPMg group significantly increased from $24 \mathrm{~h}$ to $36 \mathrm{~h}$, and continued to increase after $36 \mathrm{~h}$ until it reached a higher biomass state than the NP and EP groups after $36 \mathrm{~h}$. The result demonstrated that the decreased growth of $B$. choshinensis by PLD expression was due to its toxicity, while the addition of $\mathrm{Mg}^{2+}$ attenuated the toxic effect of PLD on cells, exhibiting a positive effect on the growth of $B$. choshinensis. As depicted in Fig. 6f, the PLD activity of the EPMg group was higher than the EP group during the entire growth process, indicating that $\mathrm{Mg}^{2+}$ effectively promoted the expression of PLD. Besides, PLD activity in the EP group decreased after $36 \mathrm{~h}$, showing the same change in its biomass. Furthermore, the analyzed cells began to die after $36 \mathrm{~h}$ due to the high toxicity of PLD expression, which might cause the intracellular protease leakage leading to the degradation of extracellular PLD.

\section{Discussion}

Studies have elucidated the mechanism underlying the toxicity of PLD overexpression to cells and protection of the PLD-imposed cells by $\mathrm{Mg}^{2+}$. The abnormal cellular physiology was mediated by the cytotoxicity of PLD, especially due to the imbalance of intracellular ionic homeostasis. Of the above cases, $\mathrm{Ca}^{2+}$ significantly affected cellular physiology. $\mathrm{Ca}^{2+}$ is a highly versatile signaling molecule controlling numerous functions during the entire life cycle of cells $[36,37]$ and a powerful uncoupling agent, with a high affinity to the electron transfer system. Mitochondrial calcium overloaded the decoupled oxidative phosphorylation and hindered energy production [38], resulting in reduced and disordered cell functions $[39,40]$. Similarly, Tomasz Wegierski has reported that TRPP2, the ion channel mutated in the autosomal dominant polycystic kidney disease (ADPKD), could protect cells from apoptosis by lowering $\mathrm{Ca}^{2+}$ concentration in the endoplasmic reticulum (ER) [41]. These studies suggested that excessive intracellular $\left[\mathrm{Ca}^{2+}\right]$ could cause damage to the cells, even cell death. Besides, $\left[\mathrm{Mg}^{2+}\right]$ needs further attention as the significant decrease of $\left[\mathrm{Ca}^{2+}\right]$ was accompanied by the significant increase of $\left[\mathrm{Mg}^{2+}\right]$ in the EPMg group, which was conducive to cell recovery and growth. The increase of $\left[\mathrm{Ca}^{2+}\right]$ by PLD expression in $B$. choshinensis was effectively alleviated under $\mathrm{Mg}^{2+}$ stress, which redistributed the intracellular ions, especially decreased $\left[\mathrm{Ca}^{2+}\right]$ influx, and increased the growth status of B. choshinensis.

The secretion of signal peptide in the vector pNCM02-PLD, derived from the MWP of Bacillus brevis 47 [26], led the precursor of PLD through the cytoplasmic membrane and then folded into mature proteins [35]. Gong reported that the expression of Stv. Cinnamoneus PLD in Bacillus subtilis resulted in the production of inclusion bodies due to excessive promoter strength [42]. Huang et al. reported that during the expression of Streptomyces racemochromogenes PLD in Bacillus subtilis WB600, the extracellular PLD activity controlled by the highest-strength P43 promoter was lower than the relatively weak PHpall promoter [43]. Moreover, the signal peptides with different secretion folding efficiency caused different extracellular PLD activity. These results suggested that the matching degree plays a vital role between the 
promoter strength and secretion efficiency of the signal peptide. When pullulanase was expressed by $B$. choshinensis, it was found that $\mathrm{Mg}^{2+}$ reduced the transcription level of the pullulanase gene, leading to the extracellular secretion of pullulanase in the correct form after fully folded [44]. The effect of $\mathrm{Mg}^{2+}$ on PLD in this study was consistent with its effects on pullulanase expression, indicating similar mechanism. In EP group, the P2 promoter exhibited a high transcriptional level of the PLD gene, leading to a higher protein synthesis and hasty cytotoxicity. As for the EPMg group, $\mathrm{Mg}^{2+}$ specifically inhibited the P2 promoter activity to maintain an appropriate transcriptional level during the growth stage, which ensured that PLD was properly secreted into the culture medium, thereby the cytotoxicity induced by high PLD expression was alleviated.

Proteins may misfold resulting accumulation in cells when the secretion could not match the expression [45]. Without $\mathrm{Mg}^{2+}$ stress, more PLD accumulated in cells (Fig. 5) and acquired lower PLD activity (Fig. 3) which provided evidence for the existence of misfolded PLD to a certain extent. Fast PLD expression under the control of $\mathrm{P} 2$ promoter overloaded the protein secretion pathway, inducing incorrect forms of PLD and reducing the its expression. It is speculated that high extracellular PLD expression has a connection with protein secretion efficiency and its correct folding. $\mathrm{Mg}^{2+}$ inhibited PLD expression in early stage to promote secretion efficiency matching expression and reduce PLD accumulation in cells. Therefore, cells could keep a continuous growth to produce PLD. However, there was a large amount of protein leakage accompanied by the PLD expression and secretion. It could also be meaningful for further research on PLD by exploring how to reduce the impact of PLD on cell leakage.

\section{Conclusions}

To the best of our knowledge, this is the first study to report PLD expression in $B$. choshinensis. Studies showed a potential extracellular expression system with high PLD expression for industrial production. Overall, further investigation is necessitated to identify the underlying mechanism behind $\mathrm{Mg}^{2+}$-induced protection of the PLD-imposed cells by omics, while the bioreactor culture could obtain the higher PLD yield. This could be an alternative approach to meet the needs for economically viable production of rare bioactive phospholipids.

\section{Materials And Methods}

\section{Materials and strains}

Brevibacillus choshinensis (Takara Bio Inc.) was used to express phospholipase D. Plasmid pNY326 and pNCMO2 (Takara Bio Inc.) were used as the expression vector. The strain E. coli JM109 (Takara Bio Inc.) was used as the cloning host. Other chemicals, unless otherwise noted, were purchased from Sinopharm Chemical Reagent Co. Ltd. (SCRC; Shanghai, China)

\section{Cultivation medium and conditions}


E. coli JM109 was cultured on the Luria broth (LB) medium containing $10.0 \mathrm{~g} / \mathrm{L}$ tryptone, $5.0 \mathrm{~g} / \mathrm{L}$ yeast extract, and $10.0 \mathrm{~g} / \mathrm{L} \mathrm{NaCl}$, with the introduction of $50 \mathrm{mg} / \mathrm{L}$ Ampicillin (Amp) to each culture. In the shake-flask culture, the primary inoculum of $B$. choshinensis was grown for $24 \mathrm{~h}$ in the $250-\mathrm{mL}$ baffled flasks containing $50 \mathrm{~mL}$ of TM medium at $30^{\circ} \mathrm{C}$ and $120 \mathrm{rpm}$ in a shaker until OD $600=2 \sim 3$. Subsequently, the seed culture $(0.5 \mathrm{~mL})$ was diluted to $50 \mathrm{~mL}$ of medium $A$ in a $250-\mathrm{mL}$ shake flask at 30 ${ }^{\circ} \mathrm{C}$ and $120 \mathrm{rpm}$. The TM medium contained $10.0 \mathrm{~g} / \mathrm{L}$ glucose, $10.0 \mathrm{~g} / \mathrm{L}$ tryptone, $5.0 \mathrm{~g} / \mathrm{L}$ beef extract, 2.0 $\mathrm{g} / \mathrm{L}$ yeast extract, $10.0 \mathrm{mg} / \mathrm{L} \mathrm{FeSO}_{4} \cdot 7 \mathrm{H}_{2} \mathrm{O}, 10.0 \mathrm{mg} / \mathrm{L} \mathrm{MnSO}_{4} \cdot 4 \mathrm{H}_{2} \mathrm{O}$, and $1.0 \mathrm{mg} / \mathrm{L} \mathrm{ZnSO}{ }_{4} \cdot 7 \mathrm{H}_{2} \mathrm{O}$. Medium A contained: $30 \mathrm{~g} / \mathrm{L}$ glucose, $30.0 \mathrm{~g} / \mathrm{L}$ beef extract, $25.0 \mathrm{~g} / \mathrm{L}$ yeast extract, and $100 \mathrm{mM} \mathrm{MgSO}_{4}$ (It was the optimum concentration after optimization). The contents were modified according to the medium reported by Chun Zou et al [32].

\section{Construction of two phospholipase $D$ expression vectors}

The PLD gene from Streptomyces antibioticus (Genebank NO. D16444, 64 kDa) with removed signal peptide was synthesized by Sangon Biotech (pUC57-PLD anti). The PLD gene was amplified by PCR using the primers 5'- TGCTCTAGAGCGGACACACCGCCCACC -3', containing an Xba I site, 5'CCGGAATTCTCAGCCCGCCTGGCGAGCCGGGC -3', containing an ECOR I site, and the plasmid pUC57-PLD anti as the template. The product was ligated into the vector pNY326 (P5 promoter) via T4 ligase (Takara Bio Inc.), then the plasmid pNY326-PLD was transformed into $B$. choshinensis. As for another expression vector, the PLD gene fragment amplified by PCR was ligated into the vector pNCMO2 (P2 promoter) via T4 ligase. The hybridized fragment was transformed into $E$. coli JM109. After being confirmed by DNA sequencing, the plasmid obtained from the transformant was transformed into $B$. choshinensis through New Tris-PEG method (Takara Bio, DaLian, China). Finally, these two recombinant strains (B.choshinensis/pNCM02-PLD and B.choshinensis/pNY326-PLD) were used for phospholipase D expression.

\section{Determination of biomass}

Cell growth was monitored by measuring the optical density of the culture broth at $600 \mathrm{~nm}$ using a microplate reader. Accurately, $4 \mathrm{~mL}$ of the culture broth was pelleted by centrifugation at $13,000 \times \mathrm{g}$ for 10 min to determine the dry cell weight (DCW). The pellet was resuspended in $0.9 \%(\mathrm{w} / \mathrm{v}) \mathrm{NaCl}$ and repelleted by centrifugation. Later, it was frozen by liquid nitrogen for 1 min, which was immediately freezedried to constant weight by a vacuum freeze drier. Finally, the biomass standard curve was plotted according to $\mathrm{OD}_{600}$ and $\mathrm{DCW}$ values.

\section{Enzyme assay}

The PLD activity was determined using phosphatidylcholine as a substrate according to the previously described method [20]. One unit of phospholipase D activity was defined as the amount of enzyme 
required to release $1 \mu \mathrm{mol}$ choline per minute from phosphatidylcholine under the specified conditions.

\section{SDS-PAGE analysis}

The celles harvested at $48 \mathrm{~h}$ were separated into two parts by centrifugation: the medium supernatant and the cell pellets. After pretreated, the extracellular and intracellular protein samples were added with $4 \times$ SDS-PAGE loading buffer with DTT (Solarbio life science, Beijing, China) and boiled for $10 \mathrm{~min}$, respectively. The proteins were separated in 10\% SDS-PAGE. ColorMixed Protein Marker 5-245KD (Solarbio life science, Beijing, China) was used to determine the apparent molecular weight of separated proteins. Proteins were visualized with Coomassie Brilliant Blue.

\section{ICP-MS}

B. choshinensis was cultured in $500-\mathrm{mL}$ shake flasks. $20 \mathrm{~mL}$ of the culture broth was pelleted by centrifugation at $6000 \times \mathrm{g}$ for $20 \mathrm{~min}$ at different time intervals. The pellet was resuspended in $1 \times \mathrm{PBS}$, and re-pelleted by centrifugation for three times, then dried to a constant weight. The dried cells with $8 \mathrm{~mL}$ of nitric acid were completely digested by microwave digestion apparatus CEM MARS6 (CEM, America). Later, the liquid was completely evaporated and the leftover was re-dissolved in $2 \%$ nitric acid. The liquid sample was filtered, and then investigated under an inductively coupled plasma mass spectrometry (ICPMS) (Agilent Technologies, America).

\section{Real-time quantitative PCR}

Total RNA was extracted using the TaKaRa MiniBEST Universal RNA Extraction Kit (Takara Bio, DaLian, China), following the manufacturer's instructions. The extracted RNA was used as the template for complementary DNA (cDNA) synthesis. The first-strand cDNA was synthesized using EasyScript ${ }^{\circledR}$ All-inOne First-Strand cDNA Synthesis SuperMix for qPCR (One-Step gDNA Removal) (TransGen Biotech, BeiJing, China), following the manufacturer's instructions.

The expression levels of the two genes encoding PLD and HWP were evaluated. The 16S rRNA gene was used as an internal control to normalize the results. The sequences of the primers used for quantitative real-time PCR (qPCR) are listed in Table 1. The qPCR analyses were performed using an ABI StepOne Real-Time PCR System (Applied Biosystems, SanMateo, CA, USA) coupled with TransStart Top Green

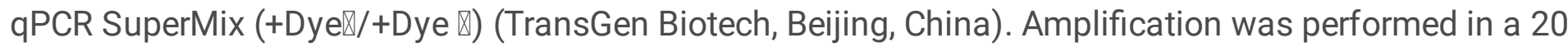
$\mu \mathrm{L}$ of mixture containing $10 \mu \mathrm{L}$ of $2 \times$ TransStart $^{\circledR}$ Top Green qPCR SuperMix (+Dye I/+Dye II), $0.4 \mu \mathrm{L}$ of forward primer, $0.4 \mu \mathrm{L}$ of reverse primer, $1 \mu \mathrm{L}$ of cDNA, and $8.2 \mu \mathrm{L}$ of nuclease-free water. The cycling program for qPCR was as follows: $94^{\circ} \mathrm{C}$ for $30 \mathrm{sec}$, followed by 40 cycles of $94^{\circ} \mathrm{C}$ for $5 \mathrm{~s}, 60^{\circ} \mathrm{C}$ for $30 \mathrm{~s}$, then dissociation. The data were analyzed by using the $2^{-\triangle \Delta C T}$ model (Livak and Schmittgen 2001). 


\section{Abbreviations}

PLD: Phospholipase D

B. choshinensis. Brevibacillus choshinensis

ICP-MS: Inductively coupled plasma-mass spectrometry

PG: Phosphatidylglycerol

PE: Phosphatidyl ethanolamine

PS: Phosphatidylserine

PI: Phosphatidylinositol

ADHD: Attention deficit and hyperactivity disorder

E. coli. Escherichia coli

HWP: HPD31 Wall Protein

ADPKD: Autosomal dominant polycystic kidney disease

ER: Endoplasmic reticulum

LB: Luria broth

Amp: Ampicillin

DCW: Dry cell weight

w/v: Weight/volume

cDNA: Complementary DNA

qPCR: Quantitative real-time

Declarations

\section{Ethics approval and consent to participate}

Not applicable.

\section{Consent for publication}




\section{Availability of data and materials}

The data supporting the results of this article are included with the article.

\section{Competing interests}

The authors declare that they have no competing interests.

\section{Funding}

This work was supported by the National Natural Science Foundation of China (No. 31871779, 21676221 and 21736009).

\section{Authors' contributions}

SC, $W X$, and $X L$ provided the idea of the research. $Y L$ and $C C$ contributed reagents, materials, and analysis tools. SC, XZ, WL, XY conducted the experiments and analyzed the data. SC, WX, XL, XZ, and WL wrote and revised the manuscript. All authors read and approved the final manuscript.

\section{Acknowledgements}

We gratefully acknowledge Fujian Collaborative Innovation Center for Exploitation and Utilization of Marine Biological Resources for their continuous support.

\section{References}

1. Damnjanović J, Iwasaki Y: Phospholipase D as a catalyst: Application in phospholipid synthesis, molecular structure and protein engineering. J Biosco Bioeng. 2013; 116:271-280.

2. Hong Y, Yuan S, Sun L, Wang X, Hong Y: Cytidinediphosphate-diacylglycerol synthase 5 is required for phospholipid homeostasis and is negatively involved in hyperosmotic stress tolerance. Plant $\mathrm{J}$ 2018; 94:1038-1050.

3. Czolkoss S, Fritz C, Hölzl G, Aktas M: Two Distinct Cardiolipin Synthases Operate in Agrobacterium tumefaciens. PLOS ONE. 2016; 11:e0160373.

4. Takaoka R, Kurosaki $\mathrm{H}$, Nakao $\mathrm{H}$, Ikeda $\mathrm{K}$, Nakano M: Formation of asymmetric vesicles via phospholipase D-mediated transphosphatidylation. BBA-Biomembranes. 2018; 1860:245-249. 
5. Choojit S, Bornscheuer UT, Upaichit A, H-Kittikun A: Efficient phosphatidylserine synthesis by a phospholipase D from Streptomyces sp. SC734 isolated from soil-contaminated palm oil. Eur J Lipid Sci Tech. 2016; 118:803-813.

6. Zhou W-B, Gong J-S, Hou H-J, Li H, Lu Z-M, Xu H-Y, et al: Mining of a phospholipase D and its application in enzymatic preparation of phosphatidylserine. Bioengineered. 2018; 9:80-89.

7. Plonski N-M, Bissoni B, Arachchilage MH, Romstedt K, Kooijman EE, Piontkivska H: Shedding light on lipid metabolism in Kinetoplastida: A phylogenetic analysis of phospholipase D protein homologs. Gene. 2018; 656:95-105.

8. Damnjanović J, Takahashi R, Suzuki A, Nakano H, Iwasaki Y: Improving thermostability of phosphatidylinositol-synthesizing Streptomyces phospholipase D. Protein Eng Des Sel. 2012; 25:415424.

9. Lopez C, Briard-Bion V, Menard O, Rousseau F, Pradel P, Besle J-M: Phospholipid, Sphingolipid, and Fatty Acid Compositions of the Milk Fat Globule Membrane are Modified by Diet. J Agr Food Chem. 2008; 56:5226-5236.

10. Ramrakhiani L, Chand S: Recent Progress on Phospholipases: Different Sources, Assay Methods, Industrial Potential and Pathogenicity. Appl Biochem Biotech. 2011; 164:991-1022.

11. Vance JE, Tasseva G: Formation and function of phosphatidylserine and phosphatidylethanolamine in mammalian cells. BBA-Mol Cell Biol L. 2013; 1831:543-554.

12. Crook TH, Tinklenberg J, Yesavage J, Petrie W, Nunzi MG, Massari DC: Effects of phosphatidylserine in age-associated memory impairment. Neurology. 1991; 41:644.

13. Moré MI, Freitas U, Rutenberg D: Positive Effects of Soy Lecithin-Derived Phosphatidylserine plus Phosphatidic Acid on Memory, Cognition, Daily Functioning, and Mood in Elderly Patients with Alzheimer's Disease and Dementia. Adv Ther. 2014; 31:1247-1262.

14. Hirayama S, Terasawa K, Rabeler R, Hirayama T, Inoue T, Tatsumi Y, et al: The effect of phosphatidylserine administration on memory and symptoms of attention-deficit hyperactivity disorder: a randomised, double-blind, placebo-controlled clinical trial. J Hum Nutr Diet 2014; 27:284291.

15. Arranz-Martínez P, Casado V, Reglero G, Torres CF: Novel glyceryl ethers phospholipids produced by solid to solid transphosphatidylation in the presence of a food grade phospholipase D. Eur J Lipid Sci Tech. 2017; 119:1600427.

16. Song S, Cheong L-Z, Guo Z, Kristensen K, Glasius M, Jensen HM, et al: Phospholipase D (PLD) catalyzed synthesis of phosphatidyl-glucose in biphasic reaction system. Food Chem 2012; 135:373379.

17. Dippe M, Mrestani-Klaus C, Schierhorn A, Ulbrich-Hofmann R: Phospholipase D-catalyzed synthesis of new phospholipids with polar head groups. Chem Phys Lipids. 2008; 152:71-77.

18. Hatanaka T, Negishi T, Mori K: A mutant phospholipase D with enhanced thermostability from Streptomyces sp. BBA-Proteins Proteom. 2004; 1696:75-82. 
19. Matsumoto Y, Kashiwabara N, Oyama T, Murayama K, Matsumoto H, Sakasegawa S-i, et al: Molecular cloning, heterologous expression, and enzymatic characterization of lysoplasmalogenspecific phospholipase D from Thermocrispum sp. FEBS Open Bio. 2016; 6:1113-1130.

20. Xiong W, Zeng X, Ho S-H, Ling X, Shen L, Yao C, et al: Strategies for achieving high-level and stable production of toxic Streptomyces phospholipase D in Escherichia coli. J Chem Technol Biot. 2019; 94:1220-1229.

21. Ogino C, Kanemasu M, Hayashi Y, Kondo A, Shimizu N, Tokuyama S, et al: Over-expression system for secretory phospholipase D by Streptomyces lividans. Appl Microbiol Biot. 2004; 64:823-828.

22. Nakazawa Y, Sagane Y, Sakurai S-i, Uchino M, Sato H, Toeda K, et al: Large-Scale Production of Phospholipase D from Streptomyces racemochromogenes and Its Application to Soybean Lecithin Modification. Appl Biochem Biotech. 2011; 165:1494-1506.

23. Ogino C, Daido H, Ohmura Y, Takada N, Itou Y, Kondo A, et al: Remarkable enhancement in PLD activity from Streptoverticillium cinnamoneum by substituting serine residue into the GG/GS motif. BBA-Proteins Proteom. 2007; 1774:671-678.

24. Zhang Y-N, Lu F-P, Chen G-Q, Li Y, Wang J-L: Expression, Purification, and Characterization of Phosphatidylserine Synthase from Escherichia coli K12 in Bacillus subtilis. J Agr Food Chem. 2009; 57:122-126.

25. Xiong W, Luo W, Zhang X, Pan X, Zeng X, Yao C, et al: High expression of toxic Streptomyces phospholipase D in Escherichia coli under salt stress and its mechanism. AIChE. 2020; 66:e16856.

26. Mizukami M, Hanagata H, Miyauchi A: Brevibacillus Expression System: Host-Vector System for Efficient Production of Secretory Proteins. Curr Pharm Biotechno. 2010; 11:251-258.

27. D'Urzo N, Martinelli M, Nenci C, Brettoni C, Telford JL, Maione D: High-level intracellular expression of heterologous proteins in Brevibacillus choshinensis SP3 under the control of a xylose inducible promoter. Microb Cell Fact. 2013; 12:12.

28. Kashima Y, Udaka S: High-level Production of Hyperthermophilic Cellulase in the Bacillus brevis Expression and Secretion System. Biosci Biotech Bioch. 2004; 68:235-237.

29. Mu T, Liang W, Ju Y, Wang Z, Wang Z, Roycik MD, et al: Efficient soluble expression of secreted matrix metalloproteinase 26 in Brevibacillus choshinensis. Protein Expres Purif. 2013; 91:125-133.

30. Mizukami M, Tokunaga H, Onishi H, Ueno Y, Hanagata H, Miyazaki N, et al: Highly efficient production of $\mathrm{VHH}$ antibody fragments in Brevibacillus choshinensis expression system. Protein Expres Purif. 2015; 105:23-32.

31. Adachi T, Yamagata H, Tsukagoshi N, Udaka S: Repression of the cell wall protein gene operon in Bacillus brevis 47 by magnesium and calcium ions. J Bacteriol. 1991; 173:4243-4245.

32. Zou C, Duan X, Wu J: Efficient extracellular expression of Bacillus deramificans pullulanase in Brevibacillus choshinensis. J Ind Microbiol Biot. 2016; 43:495-504.

33. Grycova L, Sklenovsky P, Lansky Z, Janovska M, Otyepka M, Amler E, et al: ATP and magnesium drive conformational changes of the $\mathrm{Na}^{+} / \mathrm{K}^{+}$-ATPase cytoplasmic headpiece. BBA-Biomembranes. 2009; 
1788:1081-1091.

34. Ebisu S, Tsuboi A, Takagi H, Naruse Y, Yamagata H, Tsukagoshi N, et al: Conserved structures of cell wall protein genes among protein-producing Bacillus brevis strains. J Bacteriol. 1990; 172:13121320.

35. Udaka S, Yamagata H: Protein secretion in Bacillus brevis. Anton van Leeuw. 1993; 64:137-143.

36. Li M, Kratzer E, Inoue K, Simon RP, Xiong Z-G: Developmental change in the electrophysiological and pharmacological properties of acid-sensing ion channels in CNS neurons. J Physiol. 2010; 588:38833900.

37. Samways DSK, Harkins AB, Egan TM: Native and recombinant ASIC1a receptors conduct negligible $\mathrm{Ca}^{2+}$ entry. Cell Calcium. 2009; 45:319-325.

38. Li M, Inoue K, Branigan D, Kratzer E, Hansen JC, Chen JW, et al: Acid-Sensing lon Channels in Acidosis-Induced Injury of Human Brain Neurons. J Cerebr Blood F Met. 2010; 30:1247-1260.

39. Orrenius S, Zhivotovsky B, Nicotera P: Regulation of cell death: the calcium-apoptosis link. Nat Rev Mol Cell Bio. 2003; 4:552-565.

40. Rizzuto R, Pinton P, Ferrari D, Chami M, Szabadkai G, Magalhães PJ, et al: Calcium and apoptosis: facts and hypotheses. Oncogene. 2003; 22:8619-8627.

41. Wegierski T, Steffl D, Kopp C, Tauber R, Buchholz B, Nitschke R, et al: TRPP2 channels regulate apoptosis through the $\mathrm{Ca}^{2+}$ concentration in the endoplasmic reticulum. EMBO J 2009; 28:490-499.

42. Gong G: Construction of prokaryotic expression vector of PLD gene from Streptomyces cinnamoneus and optimization of expression conditions. Master. HBAU2009.

43. Tingting $H$, Xueqin L, Jianghua L, Hyun-dong S, Guocheng D, Long L, et al: Combinatorial Fine-tuning of Phospholipase D Expression by Bacillus subtilis WB600 for the Production of Phosphatidylserine. J Microbiol Biotechn. 2018; 28:2046-2056.

44. Zou C, Duan X, Wu J: Magnesium ions increase the activity of Bacillus deramificans pullulanase expressed by Brevibacillus choshinensis. Appl Microbiol Biot. 2016; 100:7115-7123.

45. Duan X, Chen J, Wu J: Optimization of pullulanase production in Escherichia coli by regulation of process conditions and supplement with natural osmolytes. Bioresource Technol. 2013; 146:379385.

\section{Tables}

Table 1 Primer sequences used in qPCR amplification 


\begin{tabular}{|lll|}
\hline Gene & Primer & Sequence $\left(5^{\prime}-3^{\prime}\right)$ \\
\hline phospholipase D & phospholipase D-F & GGCGTGGGCATCAAGGAGT \\
\hline HWP & phospholipase D-R & CGGCGTTGGTGTTGTCGTG \\
\hline HWP-F & CTCGCTTTGACTATGTACTGG \\
\hline HWP-R & TTTGGTGCCGTGACTACTTC \\
\hline & 16S rRNA-F & TCGTGTCGTGAGATGTTG \\
\hline
\end{tabular}

Figures
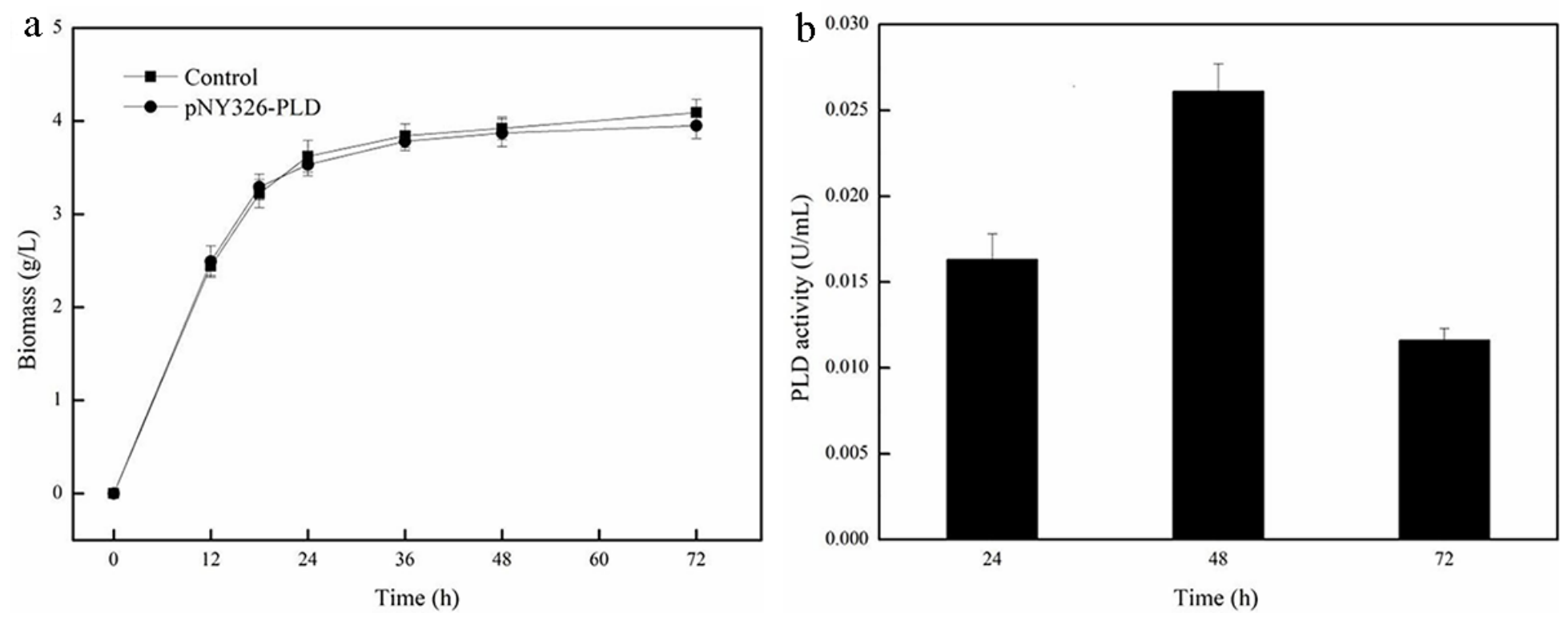

Figure 1

Growth curve and PLD activity of $B$. choshinensis/pNY326-PLD in TM medium. (a) Growth curve, the control group is the strain without plasmid. (b) PLD activity. 


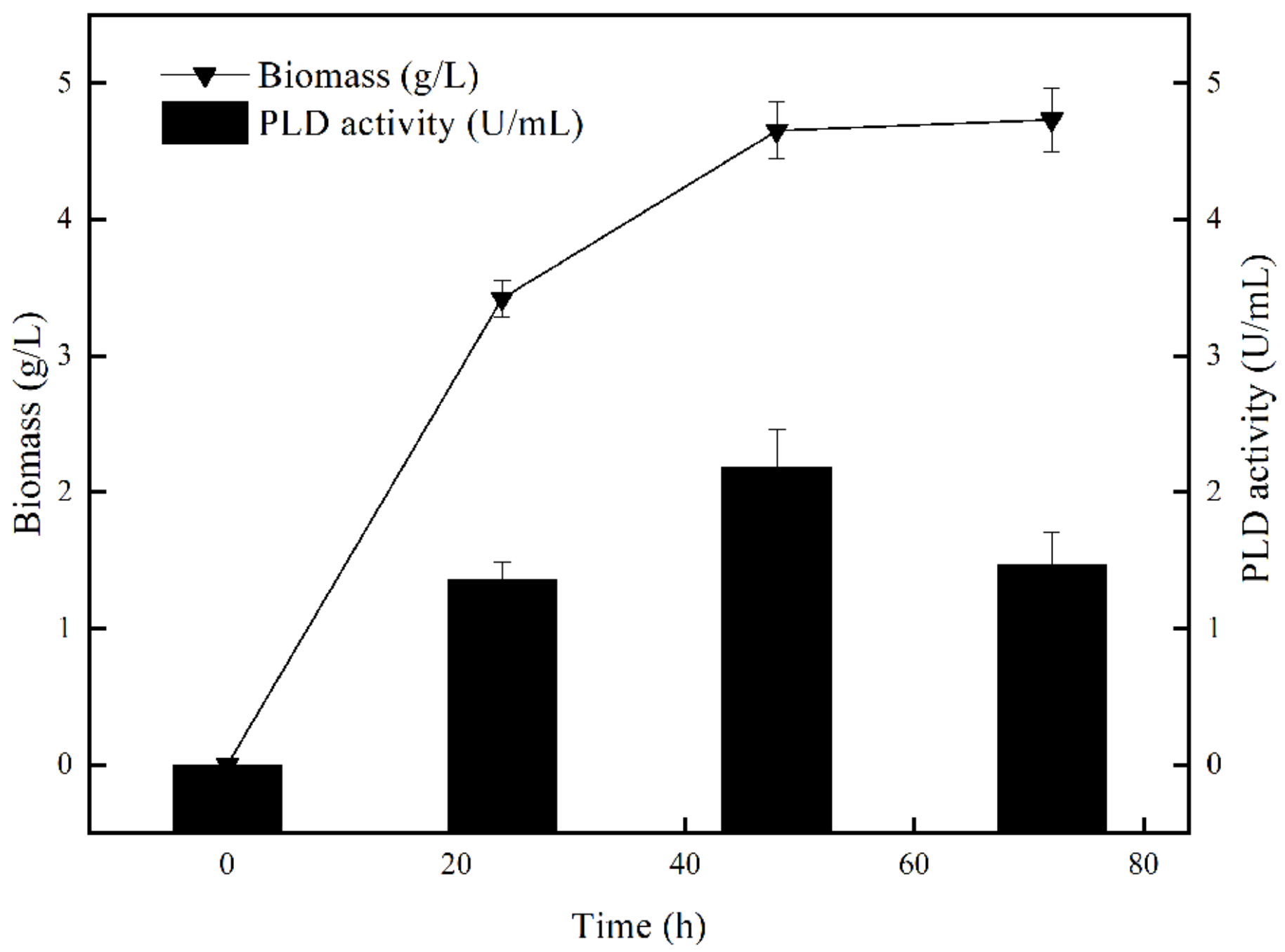

Figure 2

Growth curve and extracellular PLD expression of $B$. choshinensis/pNCMO2-PLD in TM medium with $\mathrm{Mg}^{2+}$ 


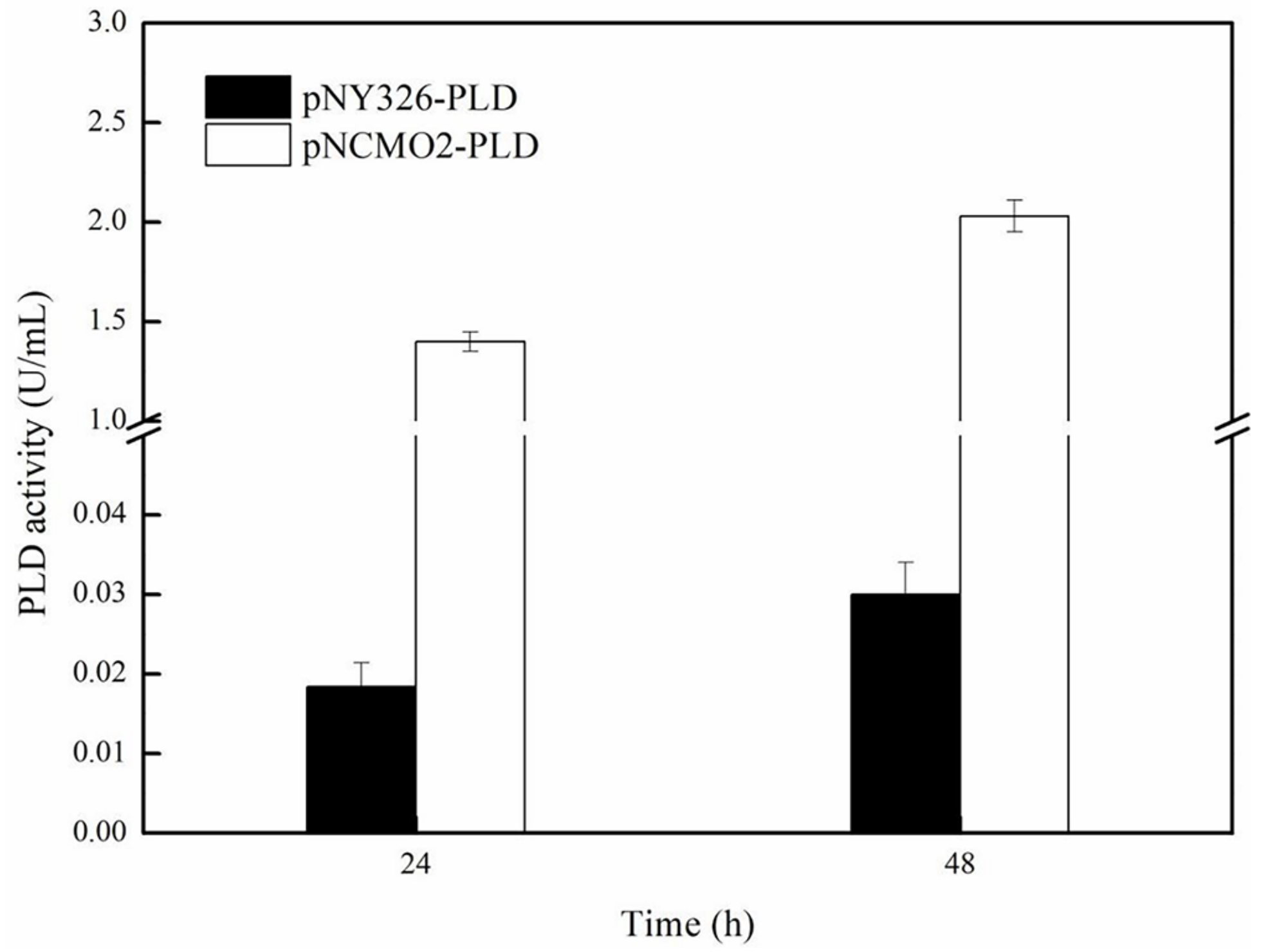

Figure 3

Effect of P5 and P2 promoter on the expression of PLD. B. choshinensis/pNY326-PLD (filled bar), pNCM02-PLD (open bar). 
a

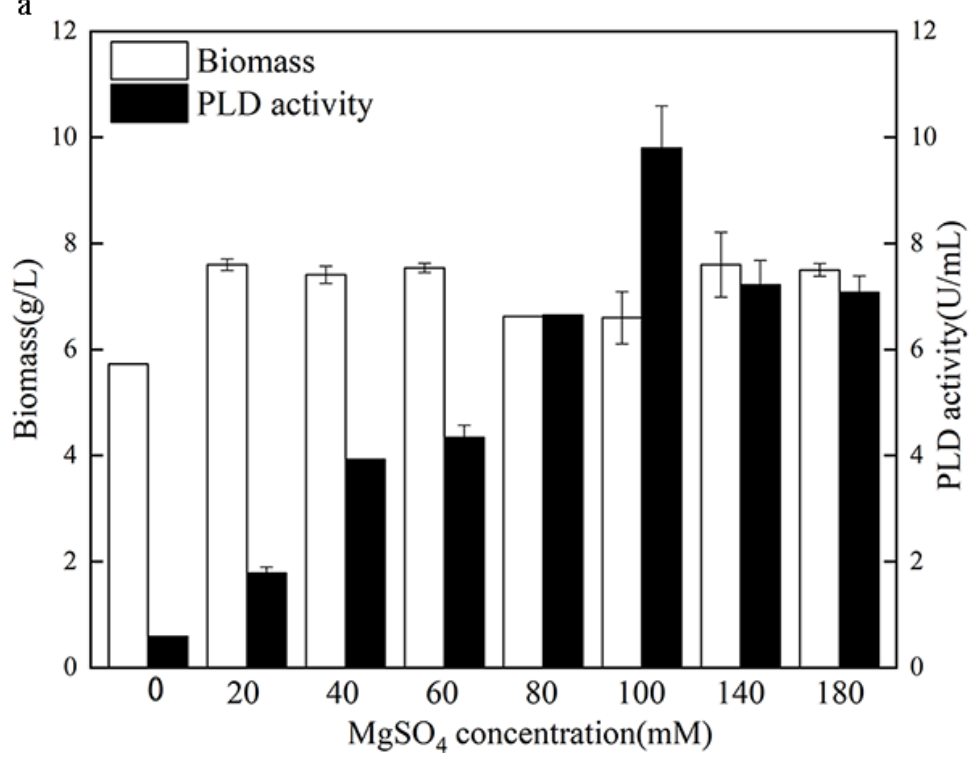

$\mathrm{b}$

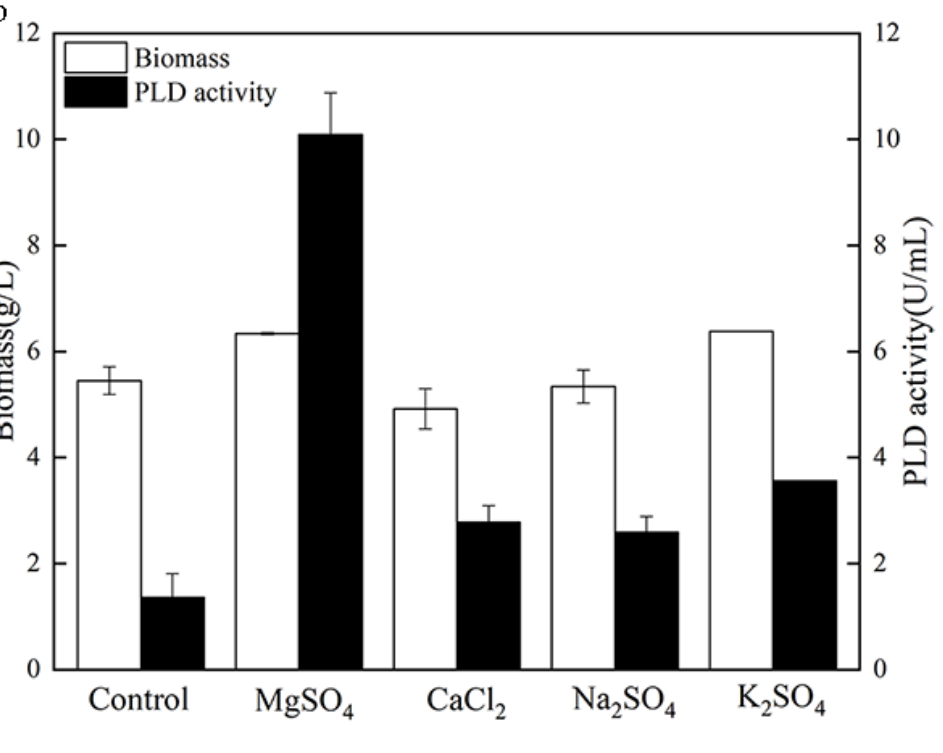

Figure 4

Effects of different conditions on the expression of PLD by B. choshinensis. (a) Different $\mathrm{MgSO}_{4}$ concentrations. (b) Different salts. Biomass (open bar), phospholipase D activity (filled bar). 

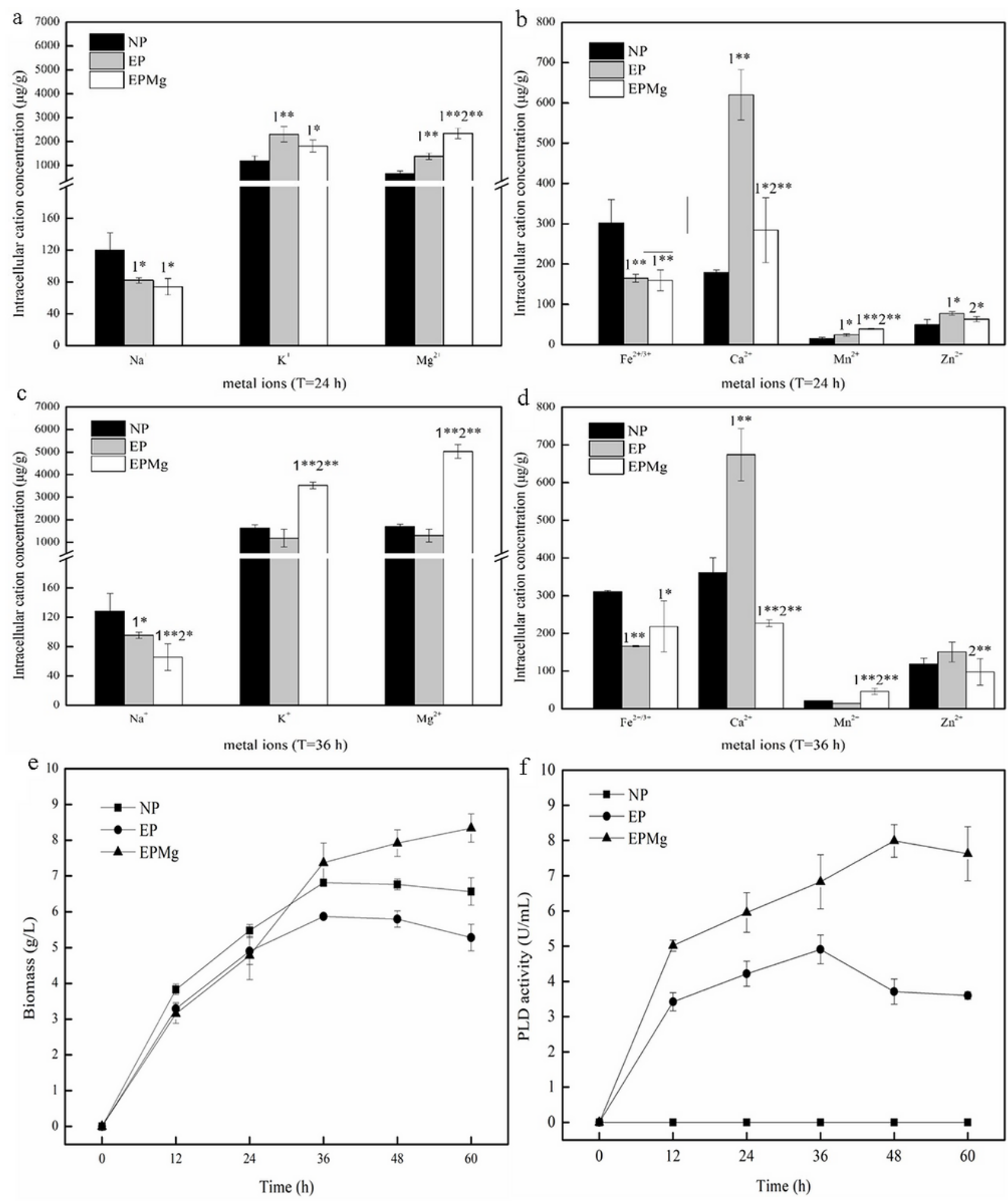

Figure 5

SDS-PAGE analysis of PLD expression. It was harvested at $48 \mathrm{~h}$. Lane 4: protein marker; lanes 1,7: intracellular and extracellular protein of $B$. choshinensis/pNCM02-PLD cultured in medium A without $\mathrm{Mg}^{2+}$; lanes 2,6: intracellular and extracellular protein of $B$. choshinensis/pNCMO2-PLD cultured in medium A; lanes 3,5: intracellular and extracellular protein of $B$. choshinensis cultured in medium A. 
$\mathrm{a}$

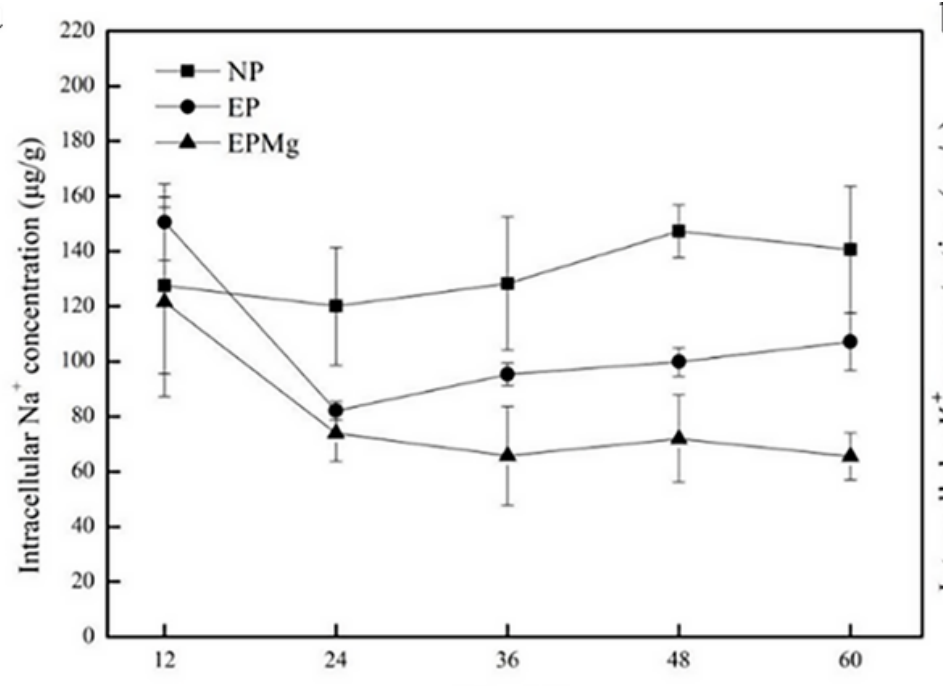

$\mathrm{C}$

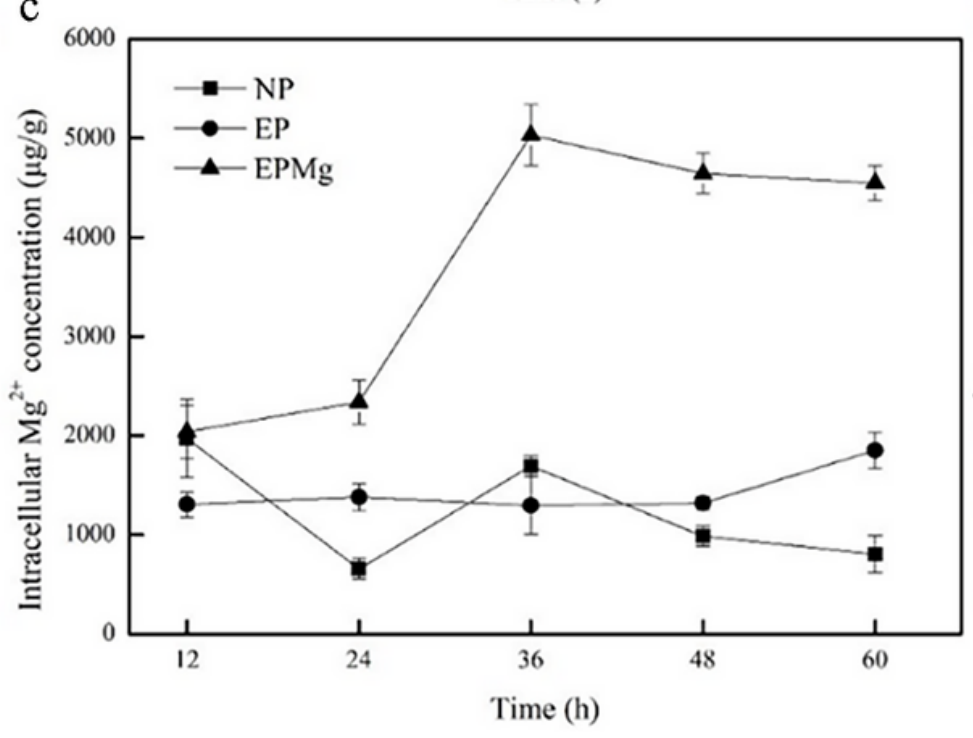

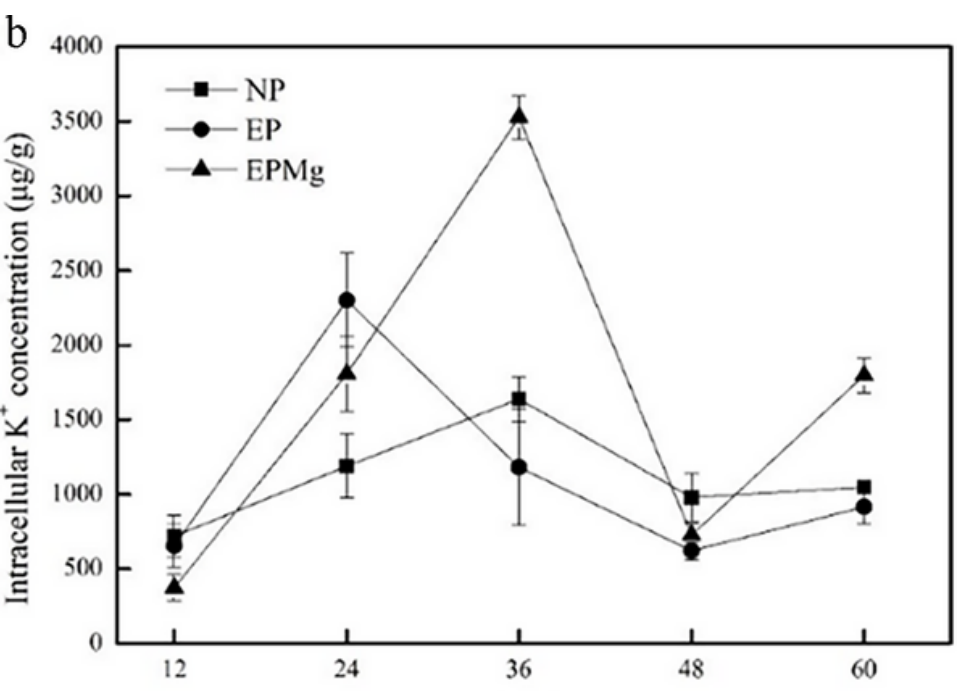

d

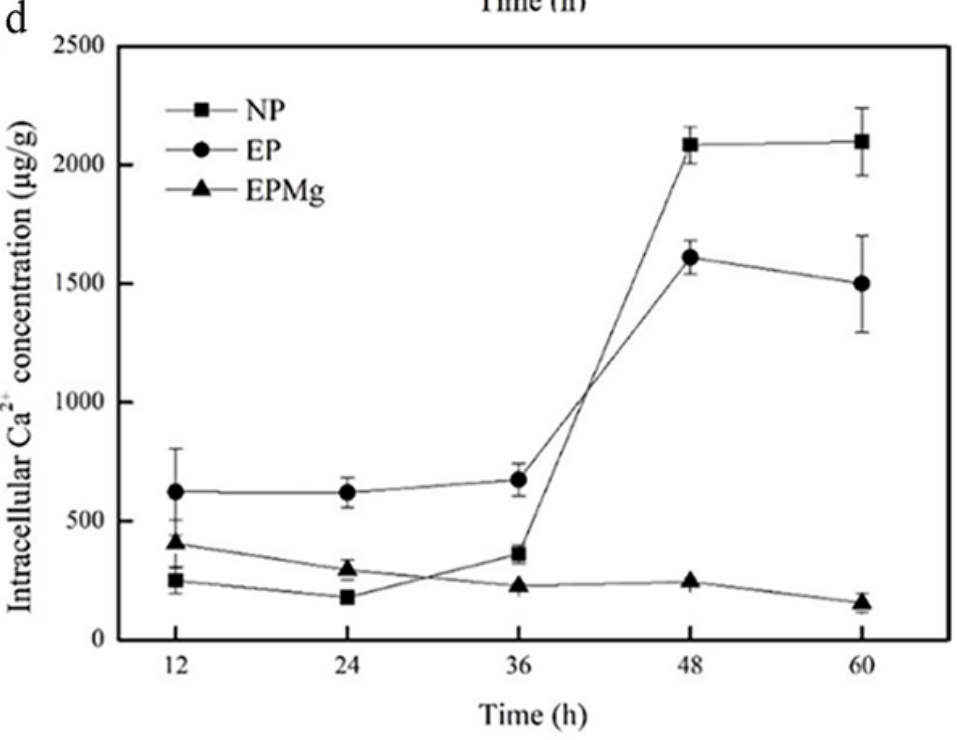

Figure 6

The concentration of ions. Intracellular $\mathrm{Na}^{+}, \mathrm{K}^{+}$, and $\mathrm{Mg}^{2+}(\mathrm{a}), \mathrm{Ca}^{2+}, \mathrm{Fe}^{2+/ 3+}, \mathrm{Zn}^{2+}$, and $\mathrm{Mn}^{2+}($ b) concentrations in groups NP, EP, EPMg at $24 \mathrm{~h}$. Intracellular $\mathrm{Na}^{+}, \mathrm{K}^{+}$, and $\mathrm{Mg}^{2+}(\mathrm{c}), \mathrm{Ca}^{2+}, \mathrm{Fe}^{2+/ 3+}, \mathrm{Zn}^{2+}$, and $\mathrm{Mn}^{2+}(\mathrm{d})$ concentrations in groups NP, EP, EPMg at $36 \mathrm{~h}$. Time-course of biomass (e) and PLD activity (f) in groups NP, NPMg, EP, EPMg. 

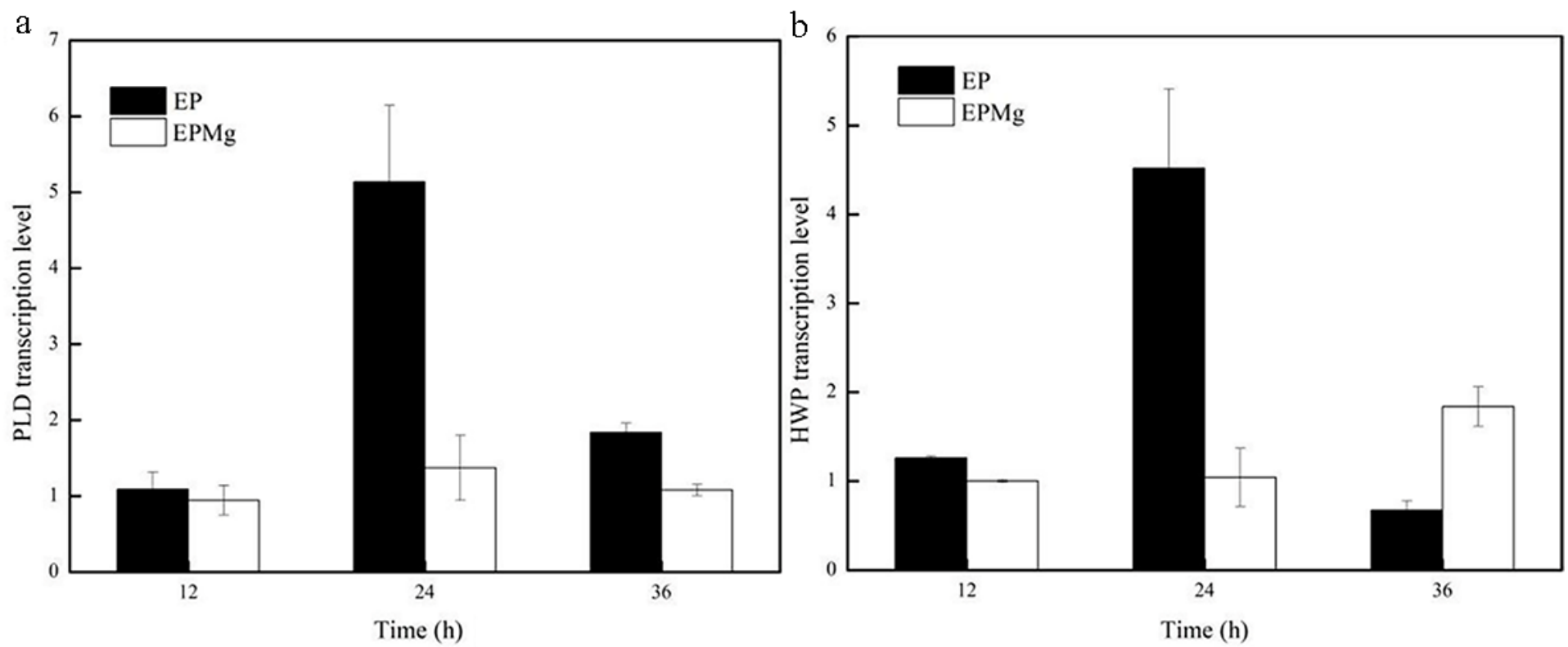

Figure 7

Curves of four ions under different conditions. (a) Intracellular [ $\left.\mathrm{Na}^{+}\right]$. (b) Intracellular [ $\left.\mathrm{K}^{+}\right]$. (c) Intracellular $\left[\mathrm{Mg}^{2+}\right]$. (d) Intracellular $\left[\mathrm{Ca}^{2+}\right]$.
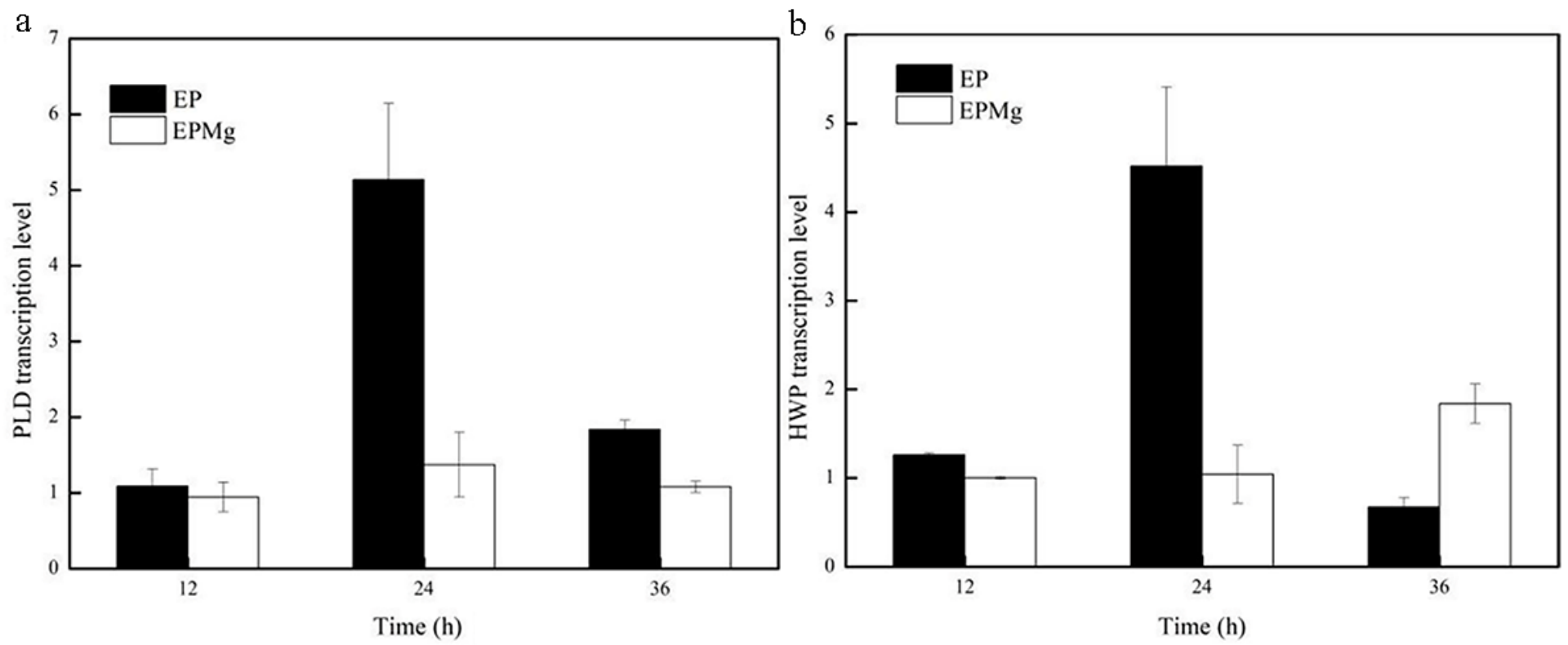

Figure 8

Transcription levels of phospholipase D and HWP genes in B. choshinensis/pNCMO2-PLD. (a) Phospholipase D. (b) HWP.

\section{Supplementary Files}

This is a list of supplementary files associated with this preprint. Click to download. 
- Supportedfiles.doc

Page 24/24 